\title{
Quercetin nanoparticles display antitumor activity via proliferation inhibition and apoptosis induction in liver cancer cells
}

\author{
KE-WEI REN, YA-HUA LI, GANG WU, JIAN-ZHUANG REN, HUI-BIN LU, \\ ZONG-MING LI and XIN-WEI HAN \\ Department of Interventional Radiology, The First Affiliated Hospital of Zhengzhou University, \\ Zhengzhou, Henan 450052, P.R. China
}

Received June 13, 2016; Accepted August 1, 2016

DOI: $10.3892 /$ ijo.2017.3886

\begin{abstract}
Quercetin is a potent cancer therapeutic agent and dietary antioxidant present in fruit and vegetables. Quercetin prevents tumor proliferation by inducing cell cycle arrest and is a well known cancer therapeutic agent and autophagy mediator. Recent studies showed that drug delivery by nanoparticles have enhanced efficacy with reduced side effects. In this regard, gold-quercetin into poly(DL-lactideco-glycolide) nanoparticles was examined. In this study, we explored the role and possible underlying mechanisms of quercetin nanoparticle in regulation of antitumor activity in liver cancer cells. Treatment with quercetin nanoparticle effectively inhibited the liver cancer cell proliferation, cell migration and colony formation, thus suppressing liver cancer progression. Quercetin nanoparticle also upregulated apoptosis markedly. Further study suggested that quercetin nanoparticle accelerated the cleavage of caspase- 9 , caspase-3, and induced the up-releasing of cytochrome $c$ (Cyto-c), contributing to apoptosis in liver cancer cells. Quercetin nanoparticles also promoted telomerase reverse transcriptase (hTERT) inhibition through reducing AP- $2 \beta$ expression and decreasing its binding to hTERT promoter. In addition, quercetin nanoparticle had an inhibitory role in cyclooxygenase $2(\mathrm{COX}-2)$ via suppressing the NF- $\mathrm{KB}$ nuclear translocation and its binding to COX-2 promoter. Quercetin nanoparticle also inactivated Akt and ERK1/2 signaling pathway. Taken together, our results suggested that quercetin nanoparticle had an antitumor effect by inactivating caspase/Cyto-c pathway, suppressing AP-2 $\beta /$ hTERT, inhibiting NF- $\kappa \mathrm{B} / \mathrm{COX}-2$ and impeding Akt/ERK1/2 signaling pathways. Our results provided new mechanistic
\end{abstract}

Correspondence to: Dr Xin-Wei Han, Department of Interventional Radiology, The First Affiliated Hospital of Zhengzhou University, 1 Jianshe Road, Zhengzhou, Henan 450052, P.R. China

E-mail: hanxinwei450052@163.com

Key words: quercetin nanoparticles, liver cancer, antitumor, proliferation, apoptosis basis for further investigation of quercetin nanoparticles to find potential therapeutic strategies and possible targets for liver cancer inhibition.

\section{Introduction}

Hepatocellular carcinoma (HCC) is a highly malignant disease with extremely poor prognosis (1). Due to its difficult early diagnosis, high malignancy, and most importantly the ineffectiveness of treatments using radiotherapy and chemotherapy, HCC is the third leading cause of cancer deaths worldwide, with more than 700,000 deaths each year $(2,3)$. Conventional surgical resection is still the major treatment strategy for HCC (4). However, the overall survival rate after hepatic resection remains low. Finding new therapeutic strategies and understanding the molecular mechanisms underlying liver tumor formation, cancer progression, recurrence and metastasis may contribute to discover more effective methods and liver cancer treatment targets.

Quercetin (3,3',4',5,7-pentahydroxy-flavone), a flavonoid found in a wide variety of plants and present in human diet (5). It is a naturally-occurring flavone that is found at high concentrations in different berries, onions, apples, and red wine (6,7). Quercetin exhibits beneficial effects on human health with its broad pharmacological properties, including anti-inflammation and anti-oxidation (8). Quercetin has selective anti-proliferative and antitumor effects via apoptotic mechanisms on different human cancer cell lines. Quercetin treatment resulted in cell cycle arrest during G0/G1 in leukemia, $\mathrm{S}$ phase in colorectal carcinoma and G2/M phases of the cell cycle in leukemia, breast carcinoma, as well as esophageal adenocarcinoma cells (9-11).

Currently, the application of polymeric drug delivery systems, including polymeric nanoparticles is regarded as one promising strategy for disease prevention or treatment (12-15). Nanoparticles have advantages in comparison to the traditional chemotherapeutic drugs. Nanoparticles may further enhance the tumor-targeted delivery through regulation of the nanoparticle surface with specific tumor or cancer cell targeting ligands, including biotin, folic acid, and antibodies (16). In addition, nanoparticles could transport 
numerous types of agents via different antitumor mechanisms, such as a chemotherapeutic drug combined with a chemosensitizer, displaying synergistic anticancer effects (17). Further, nanoparticles help to accumulate higher tumor encapsulated drugs through the promoted effect of permeability and retention (18). However, the precise molecular mechanism of quercetin nanoparticle action against liver cancer has not been elucidated, which prompted us to evaluate the effects of quercetin nanoparticles on liver cancer through apoptosis induction and proliferation inhibition in liver cancer cells.

Here, quercetin nanoparticles were used to achieve the promoted effects on liver cancer suppression through multiple cell signaling pathways. The role of quercetin nanoparticles in cell viability, cell morphology, apoptosis, colony formation, as well as cell migration was investigated in our study to reveal the underlying molecular mechanisms. It was the first time that quercetin nanoparticles inhibited liver cancer progression via regulation of signaling pathways, including

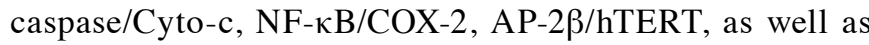
Akt/ERK1/2, which possible provide therapeutic strategies for liver cancer suppression.

\section{Materials and methods}

Quercetin nanoparticle preparation. High performance liquid chromatography (HPLC)-grade quercetin was purchased ( $>98 \%$, Sigma-Aldrich, USA) in an anhydrous powdered form. Gold nanoparticles (AuNPs) were synthesized by reducing $1 \mathrm{mM}$ gold chloride with a freshly prepared quercetin solution in absolute alcohol. The pale-yellow solution turned to deep red as the quercetin nanoparticles were formed. PLGA (50 mg) was added to an aqueous dispersion of AuNPs. Next, we added this mixture drop-wise to $20 \mathrm{ml}$ of an aqueous solution with a stabilizer (1\% polyoxyethylenepolyoxypropylene; F68). The mixture was stirred at $400 \mathrm{rpm}$ and $4^{\circ} \mathrm{C}$ until the organic solvent had evaporated completely. The redundant stabilizer was removed by repeated washing and centrifugation $\left(25,000 \mathrm{x} \mathrm{g}\right.$ and $4^{\circ} \mathrm{C}$ for $\left.30 \mathrm{~min}\right)$, and the pellet was then resuspended in Milli-Q water. The quercetin nanoparticles were stored at $4^{\circ} \mathrm{C}$ for further study. Fluorescent dye was conjugated to the gold surface by adding FITC dye to the PLGA and quercetin nanoparticle mixture, which were performed in the dark. In addition, scanning transmission electron microscopy (SEM) (FEI Quanta650, USA) was used to determine the size of naked quercetin nanoparticles. Further, dynamic light scattering (DLS) with LB-550 DLS particle size analyzer (Horiba Scientific, Edison, NJ, USA) was used to examine the average size of quercetin nanoparticles. We analyzed the data in the automatic mode. Size is presented as the mean value of 20 runs, with triplicate measurements for each run. We measured the zeta potential of the quercetin nanoparticles in the same instrument using the same procedure.

Cell culture. The human liver cancer cell lines of $\mathrm{MHCC} 97 \mathrm{H}$, Hep3B, HCCLM3 and Bel7402 were obtained from American Type Culture Collection (ATCC, VA, USA). Cells were cultured as monolayers in RPMI-1640 culture media supplemented with $10 \%$ heat-inactivated fetal bovine serum, $1 \times 10^{5}$ U/1 streptomycin sulfate, $\mathrm{pH} 7.2$ (Gibco Corp., Gaithersburg,
MD, USA) with a concentration of $1 \times 10^{6} / \mathrm{ml}$ at $37^{\circ} \mathrm{C}, 5 \% \mathrm{CO}_{2}$ at $37^{\circ} \mathrm{C}$.

Cell viability assay. Liver cancer cell viability was assessed using MTT assay (Roche Diagnosis, IN, USA). In brief, liver cancer cell lines were planted at $4 \times 10^{3}$ cells/well in 96-well plates. Cells were then cultured overnight, and next the cells were changed into fresh medium with various doses of quercetin nanoparticles dissolved in DMSO with final concentration of $0.1 \%$. After incubation for $48 \mathrm{~h}$, the cell growth was measured. The cell viability was assessed as the percent cell viability compared to the vehicle-treated control cells without quercetin nanoparticles administration, which were determined arbitrarily as $100 \%$ viability.

Colony formation assays. One hundred liver cancer cells per well in $60-\mathrm{mm}$ plates were cultured in $10 \%$ FBS DMEM. Cells were treated with quercetin nanoparticles of the indicated concentrations for $24 \mathrm{~h}$. After another 7 days of incubation, the cell colonies were washed twice with PBS, fixed with $4 \%$ paraformaldehyde for $15 \mathrm{~min}$ and then stained by Giemsa for $30 \mathrm{~min}$. Each clone with $>50$ cells were evaluated. Clone forming efficiency for cells was calculated based on: Plate colony formation inhibitory ratio $=$ (number of colonies treated with quercetin nanoparticles / number of cells inoculated) $\mathrm{x} 100 \%$.

Wound-healing assay. Wound-healing assays were carried out using migration culture dish inserts. Liver cancer cells were seeded in the chambers of the culture dish insert and transfected. Forty-eight hours after transfection, the insert was removed and fresh culture medium was added to start the migration process. Cells were treated with indicated doses of quercetin nanoparticles in full medium and kept in a $\mathrm{CO}_{2}$ incubator. After $48 \mathrm{~h}$, medium was replaced with PBS, and images were acquired using a Zeiss Axiovert 24 light microscope and an Axiocam MRc camera.

Flow cytometry assays. Flow cytometric assay was used to clarify cell apoptosis. The cells were collected with trypsinisation and then washed twice with PBS, and fixed in cold $80 \%$ ethanol, and finally stored at $4^{\circ} \mathrm{C}$ overnight. The cells were washed with PBS twice and RNase A $(10 \mathrm{mg} / \mathrm{ml})$ was administered for analysis. Propidium iodide was then added to tubes at a concentration of $0.05 \mathrm{mg} / \mathrm{ml}$ and then incubated for $20 \mathrm{~min}$ at $4^{\circ} \mathrm{C}$ in the dark. FITC-labeled Annexin V/PI staining was applied according to the manufacturer's instructions (Keygen, Nanjing, China). In brief, $1 \times 10^{6}$ cells in each well were suspended with buffer containing FITC-conjugated Annexin V/PI. Samples were then analyzed via flow cytometry.

Western blot analysis. For western blot analysis, sample tissues and cells were homogenized into $10 \%$ (wt/vol) hypotonic buffer (25 mM Tris- $\mathrm{HCl}, \mathrm{pH} 8.0,1 \mathrm{mM}$ EDTA, $5 \mu \mathrm{g} / \mathrm{ml}$ leupeptin, $1 \mathrm{mM}$ Pefabloc SC, $50 \mu \mathrm{g} / \mathrm{ml}$ aprotinin, $5 \mu \mathrm{g} / \mathrm{ml}$ soybean trypsin inhibitor, $4 \mathrm{mM}$ benzamidine) to yield a homogenate. Additionally, the final supernatants were obtained by centrifugation at $12,000 \mathrm{rpm}$ for $20 \mathrm{~min}$. Protein concentration was determined by BCA protein assay kit (Thermo, USA) with bovine serum albumin as a standard. 
Table I. Primary antibodies for western blot analysis.

\begin{tabular}{|c|c|c|}
\hline Primary antibodies & $\begin{array}{l}\text { Dilution } \\
\text { ratio }\end{array}$ & Corporation \\
\hline abbit anti-P27 & $1: 1,000$ & Abcam \\
\hline abbit anti-c-Myc & $1: 1,000$ & Abcam \\
\hline Rabbit anti-cyclin-D1 & $1: 1,000$ & Cell Signaling Technolog \\
\hline Rabbit anti-MMP7 & $1: 1,000$ & Cell Signaling Technolog \\
\hline Rabbit anti-CDK1 & $1: 1,000$ & Abcam \\
\hline Rabbit anti- $\beta$-catenin & $1: 1,000$ & Abcam \\
\hline Mouse anti-caspase-9 & $1: 1,000$ & Cell Signaling Technology \\
\hline Rabbit anti-caspase-3 & $1: 1,000$ & Cell Signaling Technology \\
\hline Rabbit anti-Cyto-c & $1: 200$ & Santa Cruz Biotechnology \\
\hline Rabbit anti-AP- $2 \beta$ & $1: 1,000$ & \\
\hline Mouse anti-hTERT & $1: 1,000$ & Cell Signaling Technolog \\
\hline Rabbit anti-COX2 & $1: 1,000$ & Abcam \\
\hline Rabbit anti-IKK $\alpha$ & $1: 1,0$ & Cell Signaling Technolo \\
\hline Rabbit anti-p-IKK $\alpha$ & $1: 1,000$ & Cell Signaling Technolog \\
\hline Mouse anti-I $\kappa \mathrm{B} \alpha$ & $1: 1,000$ & Abcam \\
\hline Mouse anti-p-IкB $\alpha$ & $1: 1,000$ & Cell Signaling Technolog \\
\hline Rabbit anti-NF- $\kappa B$ & $1: 1,000$ & Abcam \\
\hline Rabbit anti-p-NF- $\kappa \mathrm{B}$ & $1: 1,000$ & Cell Signaling Technolog \\
\hline Rabbit anti-P50 & $1: 1,000$ & Cell Signaling Technolog \\
\hline Rabbit anti-Akt & $1: 1,000$ & Cell Signaling Technolog \\
\hline Rabbit anti-p-Akt & $1: 1,000$ & Cell Signaling Technolog \\
\hline Mouse anti-Raf & $1: 1,000$ & Abcam \\
\hline Rabbit anti-ERK1/2 & $1: 1,000$ & Cell Signaling Technolog \\
\hline Rabbit anti-p-ERK1/2 & $1: 1,000$ & Cell Signaling Technology \\
\hline GAPDH & $1: 200$ & Santa Cruz Biotechnology \\
\hline
\end{tabular}

The total protein extract will be used for western blot analysis. Equal amounts of total protein of tissues were subjected to 10 or $12 \%$ SDS-PAGE followed by immunoblotting using the primary polyclonal antibodies (Table I). Immunoreactive bands were visualized by ECL Immunoblot Detection system (Pierce Biotechnology, Inc., Rockford, IL, USA) and exposed to Kodak (Eastman Kodak Co., USA) X-ray film. Each protein expression level was defined as grey value (Version $1.4 .2 \mathrm{~b}$, Mac OS X, ImageJ, National Institutes of Health, USA) and standardized to housekeeping genes (GAPDH) and expressed as a fold of control.

Real-time quantitative PCR. Total RNA from the cultured cancer cells was obtained by the miRNA Isolation kit (Sigma,
USA) according to the manufacturer's instructions. Then the cDNA was synthesized from RNA. Real-time PCR was conducted with the Applied Biosystems 7500 Sequence Detection system by the use of $\mathrm{iQ}^{\mathrm{TM}}$ SYBR Green Supermix (Bio-Rad Laboratories, USA) with $5 \mathrm{ng}$ cDNA and $10 \mathrm{pM}$ related primer. The cycling condition was conducted at $94^{\circ} \mathrm{C}$ for $60 \mathrm{sec}$; followed by 45 cycles at $95^{\circ} \mathrm{C}$ for $30 \mathrm{sec}, 58^{\circ} \mathrm{C}$ for $30 \mathrm{sec}$ and $72^{\circ} \mathrm{C}$ for $30 \mathrm{sec}$; followed by $95^{\circ} \mathrm{C}$ for $10 \mathrm{sec}, 65^{\circ} \mathrm{C}$ for $45 \mathrm{sec}$, and $40^{\circ} \mathrm{C}$ for $60 \mathrm{sec}$. The data were normalized to the housekeeping gene GAPDH and U6 small nuclear RNA expression and calculated as $2^{-\Delta \Delta C T}$ expression. The primers used are shown in Table II.

Immunofluorescence analysis. The cells grown on chamber slides were washed in PBS and fixed for $15 \mathrm{~min}$ at room temperature with $4 \%$ paraformaldehyde, followed by 20 and $30 \%$ sucrose dehydration for $24 \mathrm{~h}$ each. Then, the samples were incubated with primary antibodies (Cyto-c, P50 and $\mathrm{NF}-\kappa \mathrm{B}$, Cell Signaling Technology, USA) at $4^{\circ} \mathrm{C}$ overnight after deparaffinized and rehydrated. Fluorophore-conjugated secondary antibodies were treated for $1 \mathrm{~h}$ at $25^{\circ} \mathrm{C}$ thermostat. The Alexa Fluor 488 labeled anti-rabbit secondary antibodies (Invitrogen, CA, USA) and DAPI (Sigma-Aldrich) were used in this part. Samples were then subjected to immunofluorescence staining via epifluorescence microscopy (Sunny Co.). Leica TCS SP5 confocal microscope (Leica, Richmond Hill, ON, Canada) was used to obtain images and carried on blinded with respect to treatment groups. ImageJ 'measure' tool analyzed fluorescence intensity through examining mean intensity of each selected areas (a minimum of 10 rectangles).

Cell transfection. The transfection of targeted siRNAs or expression vectors were conducted by Lipofectamine 2000 reagent based on the manufacturer's protocol (Invitrogen).

DNA-protein binding by streptavidin-agarose pull-down assay. Streptavidin-agarose pull-down assay was used to determine the binding of AP-2 $\beta$, p50 to hTERT or COX-2 core promoter probes. A biotin-labeled double-stranded probe corresponding to hTERT and COX-2 promoter sequence was synthesized. The binding assay was applied by mixing $4 \mu \mathrm{g}$ biotinylated DNA probe, $400 \mu \mathrm{g}$ nuclear extract proteins and $40 \mu \mathrm{l} 4 \%$ streptavidin-conjugated agarose beads at room temperature for an hour in a rotating shaker. Beads were then pelleted via centrifugation in order to pull down the DNA-protein complex. After washing, proteins in complex were evaluated through immunoblotting with antibodies $(1 \mu \mathrm{g} /$ $\mathrm{ml}$ of each sample) specific for AP-2 $\beta$ and p50. The mixture was then incubated at room temperature for $1 \mathrm{~h}$ with shaking, and then centrifuged to pull down the DNA-protein complex.

Table II. Primer sequences used for real-time PCR $\left(5^{\prime} \rightarrow 3^{\prime}\right)$.

\begin{tabular}{llc}
\hline Gene & \multicolumn{1}{c}{ Forward primer } & Reverse primer \\
\hline AP-2 $\beta$ & GGAAGCGATCTGAGAAGTGCA & CACTGGGAACGGTATACTGATT \\
hTERT & CCAATCCCGCCATGATCC & GAGAACGGATCTGCCATCACA \\
GAPDH & GACTCATGACAGTCCATGACCC & AGCGGAGAATGAGGTTCTTGG \\
\hline
\end{tabular}


A

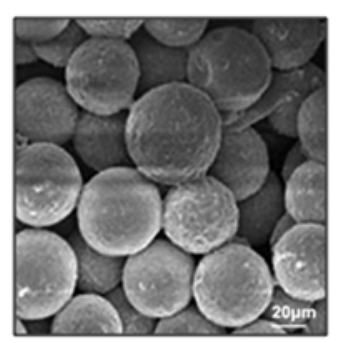

Statistics Graph (1 measurments)
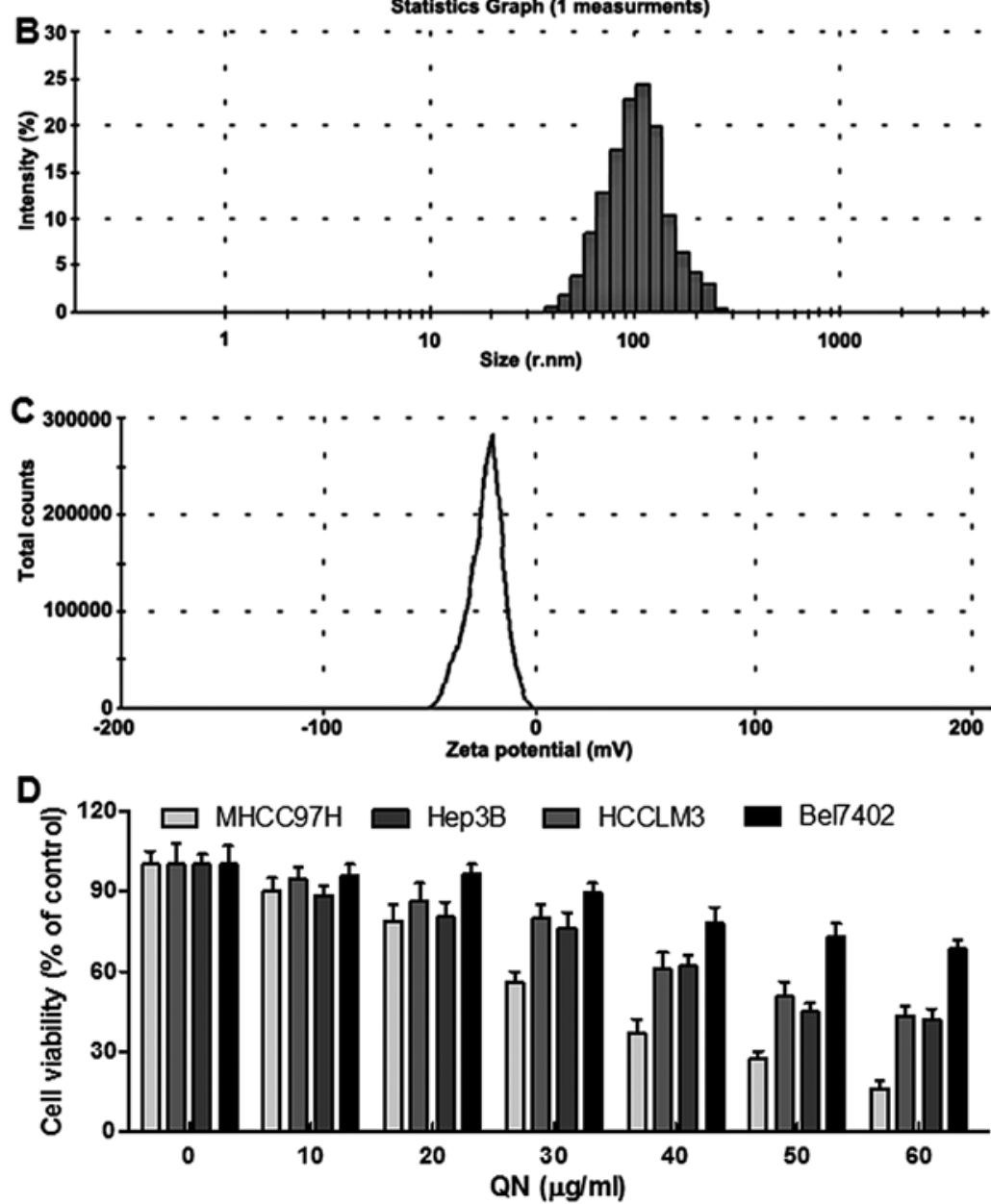

Figure 1. The size and change of quercetin nanoparticles. (A) The structure of quercetin nanoparticles via scanning electron microscopy (SEM). (B) The average particle size obtained from the nanoparticle dynamic light scattering (DLS) data. (C) Zeta potential of PLGA encapsulated quercetin nanoparticles. (D) Determination of liver cancer cell viability: 10-60 $\mu \mathrm{g} / \mathrm{ml}$ quercetin nanoparticles was administered to cultures of different liver cancer cell lines for $24 \mathrm{~h}$, including MHCC97H, Hep3B, HCCLM3 and Bel7402. MTT was used to determine cell viability, and the graph displayed a gradual reduction in liver cancer cell viability. The $\mathrm{LD}_{50}$ values of these cell lines were close to 30,40 and $50 \mu \mathrm{g} / \mathrm{ml}$. The drug concentrations of 30,40 and $50 \mu \mathrm{g} / \mathrm{ml}$ were added to $\mathrm{MHCC} 97 \mathrm{H}$ for the following studies.

DNA-bound AP- $2 \beta$ and p50 protein was dissociated and analyzed by western blotting. Non-immune rabbit $\operatorname{IgG}(1 \mu \mathrm{g} /$ $\mathrm{ml}$ ) was used as negative controls.

Establishment of xenograft tumor models. The mouse experiments were conducted in the Animal Laboratory Center. MHCC $97 \mathrm{H}$ cells $\left(1 \times 10^{7}\right.$ cells) treated with or without quercetin nanoparticles were suspended in $100-\mu \mathrm{l}$ serum-free medium and injected subcutaneously into the left flank of 4- to 6-week old male BALB/c nu/nu nude mice. After two weeks, when the tumor diameters reached $3 \times 4 \mathrm{~mm}$, the tumor cell-inoculated mice were divided into four treatment groups randomly, the control (Con) treated with PBS; the quercetin nanoparticle groups treated with 30,40 and $50 \mathrm{mg} / \mathrm{kg}$, respectively, by intraperitoneal injection every day. Tumor size was measured with digital caliper and calculated as $\mathrm{V}=\mathrm{LS} 2 / 2$ ( $\mathrm{L}$ is the longest diameter and $\mathrm{S}$ is the shortest diameter). Tumor volume and animal weight were measured twice every seven days, and at $\sim 5$ weeks after treatment, mice were sacrificed. Body weights were also recorded. Tumors were excised, weighted, fixed in $10 \%$ neutral formalin, and embedded in paraffin for histological analysis.

Immunohistochemical assays. The xenograft tumors were performed for hematoxylin and eosin staining. In brief, fresh tissues were fixed in paraffin, and for immunohistochemistry, 

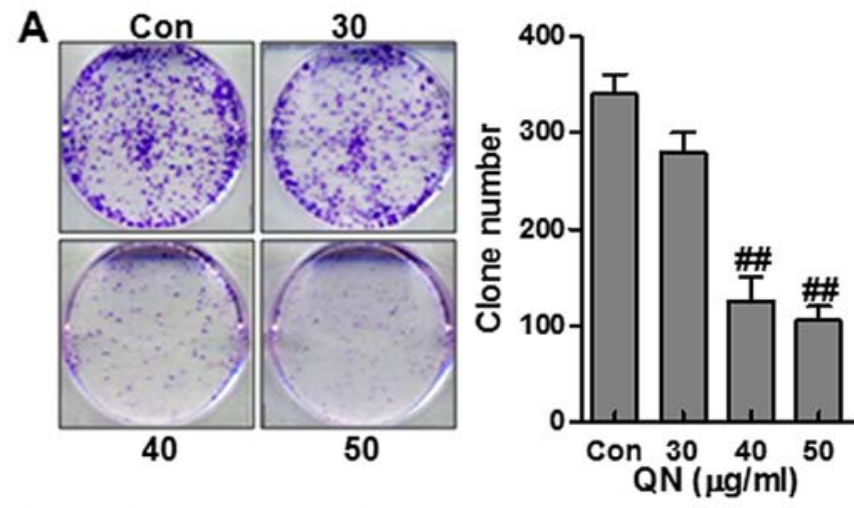

B

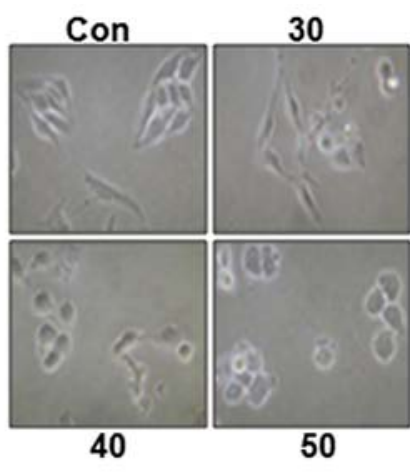

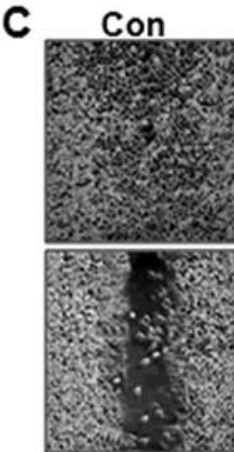

40
30

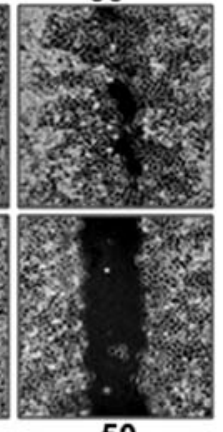

50

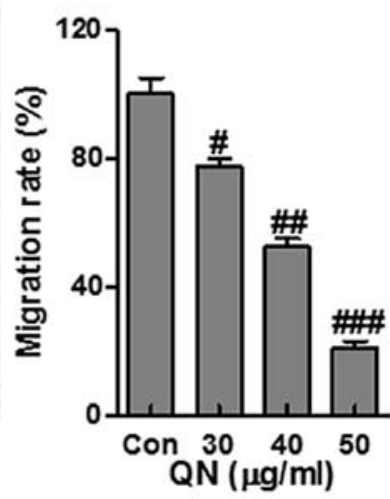

D

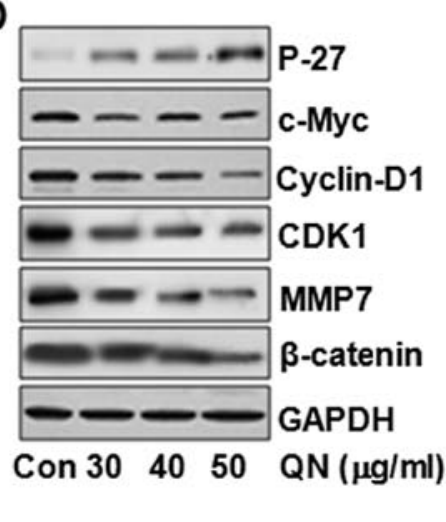

Figure 2. Quercetin nanoparticles promote the liver cancer cell growth inhibition and colony formation suppression. (A) The determination of MHCC97Hinduced colony formation. (B) The changes in MHCC97H cell morphology and spreading after treatment of different concentrations of quercetin nanoparticles for $24 \mathrm{~h}$ were studied, and MHCC97H cells were photographed via a microscope equipped with digital camera. (C) A scratch assay was conducted to analyze the cell migration. (D) Protein levels of P-27, c-Myc, cyclin-D1, CDK1, MMP7 and $\beta$-catein were measured after quercetin nanoparticle treatment via western blotting. Data are expressed as the mean \pm SEM $(\mathrm{n}=6-10) .{ }^{\#} \mathrm{p}<0.05,{ }^{\# \#} \mathrm{p}<0.01$ and ${ }^{\# \# \#} \mathrm{p}<0.001$ versus the control (Con) group.

the fresh tumor tissues were fixed in formalin for $48 \mathrm{~h}$. Then the tissue block was put in paraffin and next cut into the desired thickness with a microtome, and was then fixed into a slide. After washing, the sections were prepared for blocking and incubating with antibodies, including AP-2 $\beta$, TUNEL and COX2, which were diluted 1:100 in 5\% horse serum with PBS at $4^{\circ} \mathrm{C}$ overnight. Sections were then incubated with diluted streptavidin-peroxidase HRP conjugates at room temperature by a staining kit, according to the manufacturer's instructions. The sections were then stained with hematoxylin for $3 \mathrm{~min}$ and mounted and analyzed under a phase-contrast microscope.

Statistical analysis. Data were expressed as mean \pm standard error of the mean (SEM). Statistical analyses were performed using GraphPad PRISM (version 6.0; Graph Pad Software) by ANOVA with Dunnet's least significant difference post hoc tests. A p-value $<0.05$ was considered statistically significant.

\section{Results}

Quercetin nanoparticle is toxic to liver cancer cells. The quercetin nanoparticle surface morphology was explored by scanning electron microscopy (SEM) (Fig. 1A). The images displayed spherically-shaped quercetin nanoparticles with a smooth surface and without pinholes or cracks. The dynamic light scattering (DLS) data indicated that the mean quercetin nanoparticle diameter was $106.7 \mathrm{~nm}$ (Fig. 1B). Additionally, the zeta potential was $-19.1 \mathrm{mV}$ (Fig. 1C). In this experiment, four liver cancer cell lines, including MHCC97H, Hep3B, HCCLM3 and Bel7402, were chosen to explore whether quercetin nanoparticle was effective on liver cancer inhibition. Hence, a 24-h dose-dependent $(0-60 \mu \mathrm{g} / \mathrm{ml})$ study with MHCC97H, Hep3B, HCCLM3 and Bel7402 cells was conducted. As shown in Fig. 1D, the liver cancer cell viability decreased. Additionally, quercetin nanoparticle was much more toxic to MHCC97H cells than the other cells. Therefore, the following experiments were performed with $\mathrm{MHCC} 97 \mathrm{H}$ cells.

Quercetin nanoparticles promote the liver cancer cell growth inhibition and suppression of colony formation. We first evaluated the effects of quercetin nanoparticle on $\mathrm{MHCC} 97 \mathrm{H}$ cell growth. As shown in Fig. 2A, treatment with quercetin nanoparticle inhibited colony formation in a dose-dependent manner. We next analyzed the effect of quercetin nanoparticle on changes in cell morphology and spreading in $\mathrm{MHCC} 97 \mathrm{H}$ cells. As shown in Fig. 2B, the cells treated without quercetin nanoparticle contributed to a cell layer. In addition, more spread and filopodia was observed. In the contrast, treatment with quercetin nanoparticle significantly promoted the cell-to-cell contact and reduced the cell spreading with lower filopodia formation compared with control group, suggesting that quercetin nanoparticle enhanced alterations in $\mathrm{MHCC} 97 \mathrm{H}$ 

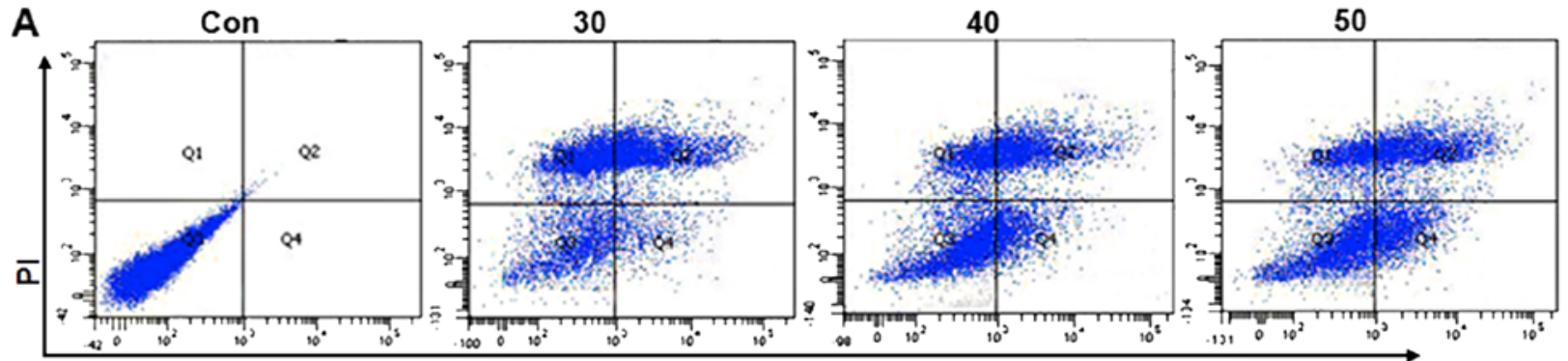

Annexin V-FITC

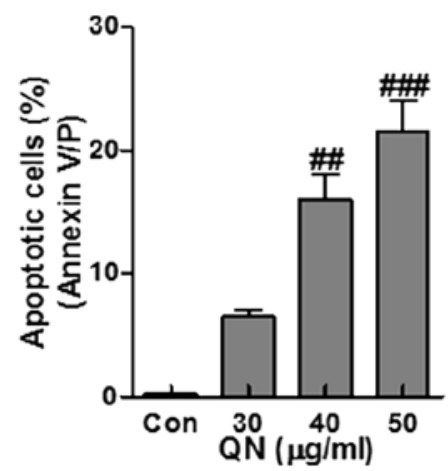

B
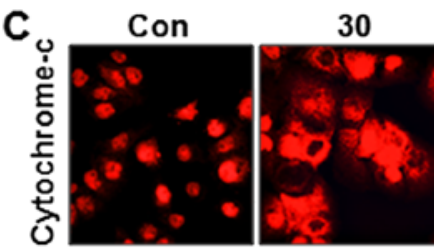

40
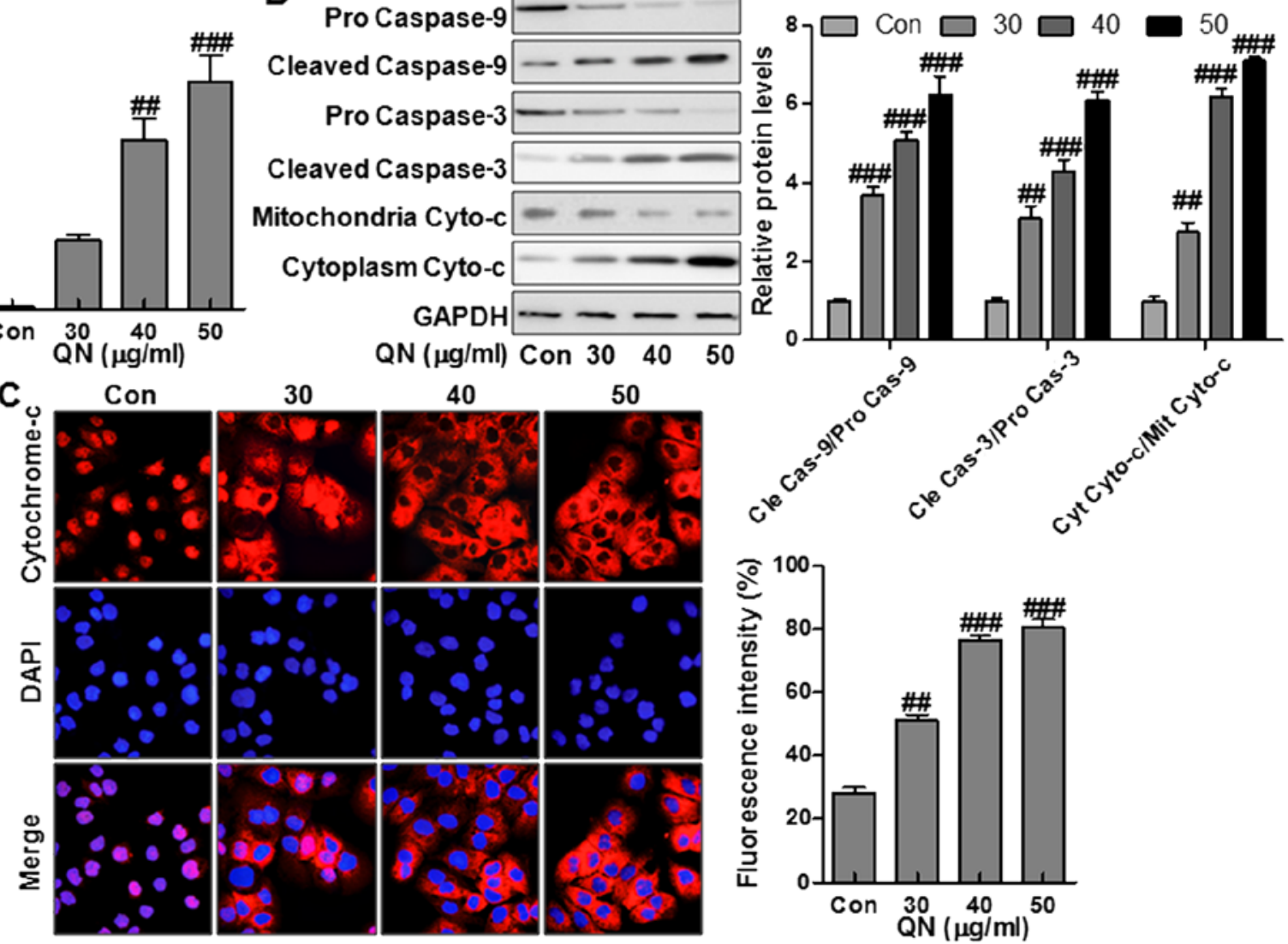

Figure 3. Quercetin nanoparticles accelerate liver cancer cell apoptosis through enhancing the activity of Cyto-c/caspase signaling. (A) Apoptosis was tested by FACS analysis after MHCC97H cells were treated with quercetin nanoparticles for $48 \mathrm{~h}$ (upper panel). The apoptotic percentage was evaluated (lower panel). (B) Western blot assays were performed to analyze the cleaved caspase-9, cleaved caspase- 3 and Cyto-c release from cytoplasm. (C) Cyto-c release was evaluated by immunofluorescence staining analysis to observe Cyto-c release from the inter-mitochondrial into cytoplasm (left). The fluorescent intensity of Cyto-c was calculated (right). Data are expressed as the mean \pm SEM $(n=6-10) .{ }^{\# \#} \mathrm{p}<0.01$ and ${ }^{\# \# \#} \mathrm{p}<0.001$ versus the control (Con) group.

cell morphology and spreading. Further, wound-healing assay was used to determine the role of quercetin nanoparticle in MHCC97H cell migration. Consistently, after making a scratch the gap and wounding space between MHCC97H cell layers was occupied partially due to the migrating cells after $48 \mathrm{~h}$ in the control group. However, the empty space was not occupied by the MHCC $97 \mathrm{H}$ cells after quercetin nanoparticle treatment, suggesting that the liver cancer cell migration was inhibited markedly after quercetin nanoparticle administration, which was dose-dependent (Fig. 2C). To further identify the possible mechanisms related to cell migration, we assessed the P-27, c-Myc, cyclin-D1, CDK1, MMP7 and $\beta$-catenin protein levels. The results showed that P-27 was expressed highly after quercetin nanoparticle treatment, displaying antitumor activity via P-27 upregulation. However, c-Myc, cyclin-D1, CDK1, MMP7 and $\beta$-catenin, important factors promoting cell cycle, were significantly downregulated after quercetin nanoparticle treatment (Fig. 2D).

Quercetin nanoparticles accelarates liver cancer cell apoptosis through enhancing the activity of Cyto-c/caspase signaling. The effect of quercetin nanoparticles on apoptosis in MHCC97H cells was studied. Treatment with quercetin nanoparticle at different doses of 30,40 , and $50 \mu \mathrm{g} / \mathrm{ml}$ was performed on the liver cancer cells (Fig. 3A). Compared to the control group, treatment with quercetin nanoparticle significantly upregulated the number of apoptotic cells (Fig. 3A). Caspase cascade activation forms the essential basis for apoptosis. Cytochrome $c$ releasing from the mitochondrial inter-membrane space into the cytoplasm is the precondition 

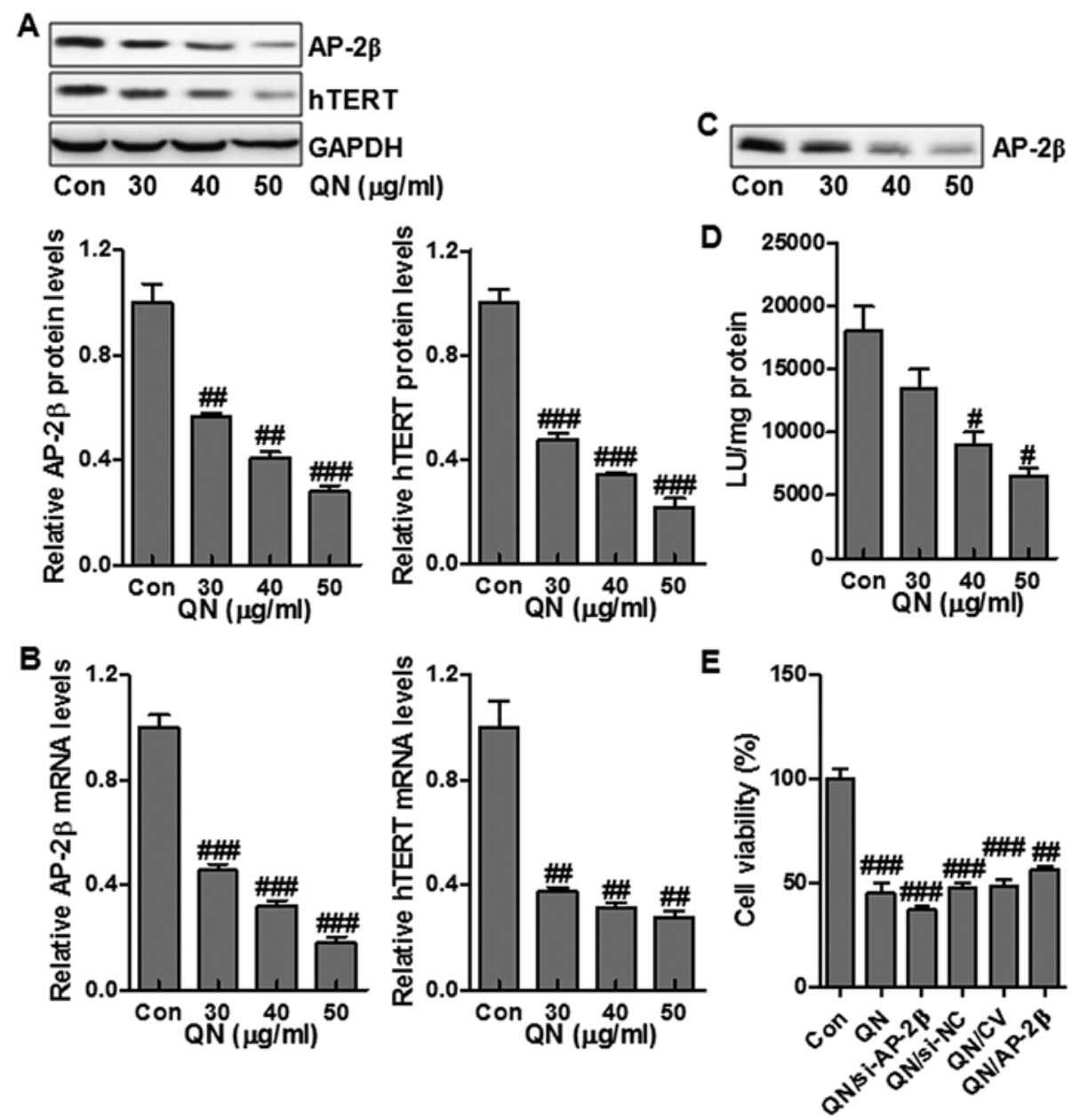

Figure 4. Quercetin nanoparticles induce liver cancer inhibition via AP-2 2 /hTERT signaling pathway suppression. (A) MHCC97H cells were treated with different concentrations of quercetin nanoparticles. After $48 \mathrm{~h}$, protein levels of AP-2 $\beta$ and hTERT were evaluated by western blotting. (B) MHCC97H cells were treated with different concentrations of quercetin nanoparticles. After $48 \mathrm{~h}$, mRNA levels of AP-2 $\beta$ and hTERT were evaluated by RT-PCR. (C) MHCC $97 \mathrm{H}$ cells were treated with quercetin nanoparticles. After $48 \mathrm{~h}$, streptavidin-agarose pull-down assay was used to determine the binding of AP-2 $\beta$ to hTERT promoter probe. (D) MHCC97H cells were treated with quercetin nanoparticles after transfection of hTERT promoter-driven luciferase plasmid. The proteins were then extracted, and the luciferase reporter assay kit was used to detect luciferase activity. (E) MHCC97H cancer cells were transfected with AP-2 $\beta$ siRNA or expressed AP-2 $\beta$ vector for $24 \mathrm{~h}$, and then treated with quercetin nanoparticles. After $48 \mathrm{~h}$, MTT assay was conducted to determine cell viability. Data are expressed as the mean \pm SEM $(n=6-10) .{ }^{\#} \mathrm{p}<0.05,{ }^{\# \#} \mathrm{p}<0.01$ and ${ }^{\# \# \#} \mathrm{p}<0.001$ versus the control (Con) group.

of caspase-dependent apoptosis pathway. Thus, we measured the expression of pro-apoptotic proteins, including caspase-9, caspase-3, and Cyto-c in MHCC97H cells via western blot analysis. Treatment with quercetin nanoparticle promoted the upregulation of the cleaved caspase-9, caspase-3 and cytoplasm Cyto-c effectively compared with the control group (Fig. 3B), indicating the effect of quercetin nanoparticle on apoptosis induction in liver cancer cells. Immunofluorescence imaging (IFI) was also performed to observe the changes of subcellular localization of Cyto-c in $\mathrm{MHCC} 97 \mathrm{H}$ cells to explore whether quercetin nanoparticle could stimulate Cyto-c release. Treatment with quercetin nanoparticle at different concentrations induced Cyto-c release from the inter-mitochondrial space into the cytoplasm (Fig. 3C). The results above demonstrated that quercetin nanoparticle might enhance the caspase activation via Cyto-c-dependent apoptosis in liver cancer cells.

Quercetin nanoparticles induce liver cancer inhibition via suppression of AP-2 $\beta / h T E R T$ signaling pathway. hTERT is a mark of tumorigenesis, which is highly modulated by transcriptional factor AP-2 $\beta$ (19). In order to determine if quercetin nanoparticle influenced the AP-2/hTERT signaling pathway in liver cancer cells, MHCC $97 \mathrm{H}$ cells were administrated with quercetin nanoparticles, and the protein and mRNA expression of AP- $2 \beta$ and hTERT were examined via western blot and RT-PCR assays. Treatment with quercetin nanoparticles reduced the hTERT and AP- $2 \beta$ protein and mRNA levels compared to the control group (Fig. 4A and B). hTERT expression is closely related to the AP- $2 \beta$ binding activity on hTERT promoter. Next, streptavidin-agarose pull-down assay was performed to test the effect of quercetin nanoparticle on AP- $2 \beta$ binding activity in $\mathrm{MHCC} 97 \mathrm{H}$ cells. Treatment with quercetin nanoparticle had a potential role in suppressing AP-2 $\beta$ protein levels (Fig. 4A), thus suppressing the binding of AP-2 $\beta$ to hTERT promoter (Fig. 4C). Further, we also explored the role of quercetin nanoparticle in regulating hTERT promoter activity. The results suggested that treatment with quercetin nanoparticle effectively inhibited hTERT promoter activity (Fig. 4D). Finally, in order to further clarify that the AP-2 $\beta$ signaling is associated with the 

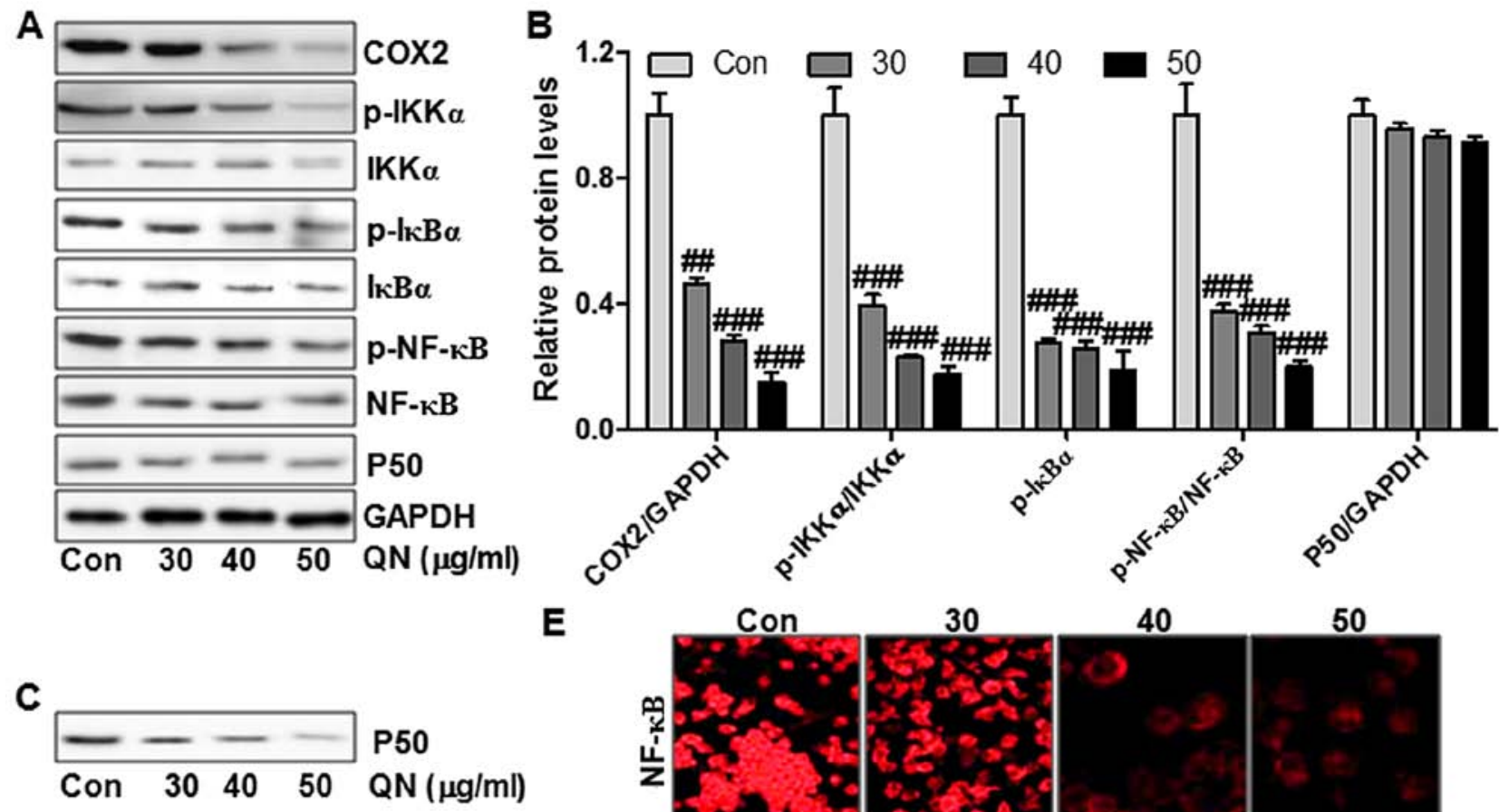

E
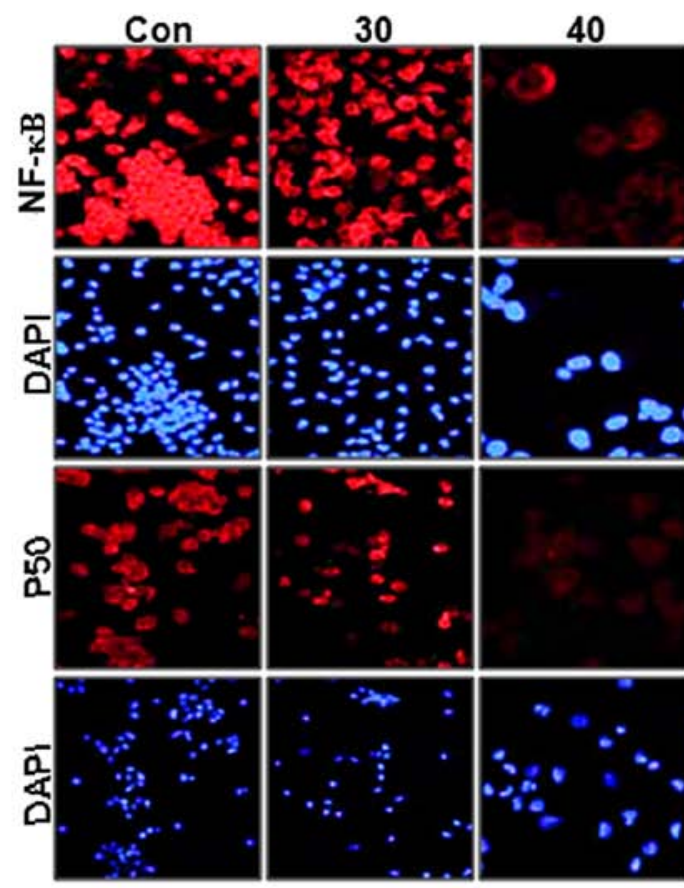

50
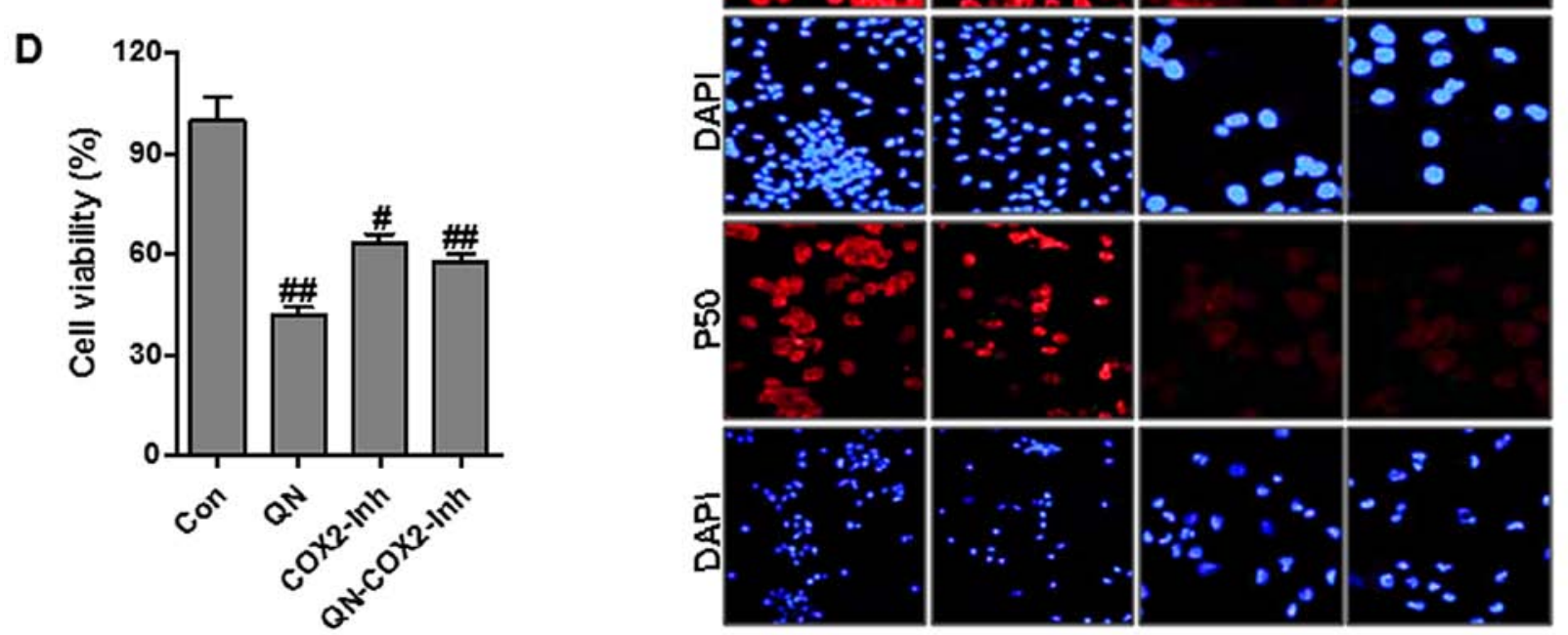

Figure 5. Quercetin nanoparticles ameliorate liver cancer progression via p65/COX-2 signaling inhibition. (A) MHCC97H cells were treated with quercetin nanoparticles. After $48 \mathrm{~h}$, western blotting was used to determine protein levels of COX-2, p-IKK $\alpha, \mathrm{p}-\mathrm{I} \kappa \mathrm{B} \alpha, \mathrm{p}-\mathrm{NF}-\kappa \mathrm{B}$ and P50. (B) Relative protein levels were calculated based on western blot assays. (C) MHCC97H cells were administrated with quercetin nanoparticles. After $48 \mathrm{~h}$, the assay of streptavidinagarose pulldown was used to evaluate the P50 binding to COX-2 promoter probe. (D) MHCC97H cells were pretreated with the selective inhibitor of COX-2 (COX2-Inh) $(20 \mu \mathrm{M})$ for $24 \mathrm{~h}$, and then treated with quercetin nanoparticles $(50 \mu \mathrm{g} / \mathrm{ml})$. After $48 \mathrm{~h}$, the liver cancer cell viability was conducted through MTT analysis. (E) MHCC97H cells grown on chamber slides were treated with quercetin nanoparticles. After $48 \mathrm{~h}$, the subcellular translocalization of p50 and NF-KB was determined via a confocal microscope. Data are expressed as the mean \pm SEM $(n=6-10) . "{ }^{*} p<0.05,{ }^{\# \#} p<0.01$ and ${ }^{\# \# \# p} p<0.001$ versus the control (Con) group.

promotion of cell growth inhibition, MHCC97H cells were transfected with $100 \mathrm{nM}$ AP- $2 \beta$ siRNA or AP-2 $\beta$-expressing vector and next cotreated with quercetin nanoparticle $(50 \mu \mathrm{g} /$ $\mathrm{ml})$. As shown in Fig. 4E, compared with the non-specific AP-2 $\beta$ siRNA control (si-NC), AP- $2 \beta$ knockdown (si-AP- $2 \beta$ ) slightly reduced the cell growth regulated by quercetin nanoparticles. Of note, AP- $2 \beta$ overexpression through AP- $2 \beta$ transfection significantly upregulated the liver cancer cell growth compared to transfection with control vector (CV) (Fig. 4E). The data above illustrated that the promotion of growth suppression by quercetin nanoparticle was regulated, at least partly, through AP-2 $\beta$ / hTERT signaling pathway inhibition in MHCC $97 \mathrm{H}$ cells.
Quercetin nanoparticles ameliorate liver cancer progression via 65/COX-2 signaling inhibition. COX-2 signaling is related to cancer cell growth, invasion, migration and proliferation $(20,21)$. In this regard, we determined the role of quercetin nanoparticle in regulating COX-2 protein levels in $\mathrm{MHCC} 97 \mathrm{H}$ cells via western blotting. Treatment with quercetin nanoparticle significantly suppressed COX-2 protein levels (Fig. 5A and $\mathrm{B}$ ). To prove that quercetin nanoparticles promoted $\mathrm{COX}-2$ signaling inhibition, MHCC97H cells were administered with COX-2-selective inhibitor (COX2-Inh) $(20 \mu \mathrm{M})$, and then treated with quercetin nanoparticle $(50 \mu \mathrm{g} / \mathrm{ml})$. Treatment with COX-2-selective inhibitor inhibited MHCC97H cell viability (Fig. 5D). However, a combination with quercetin nanoparticle 
A

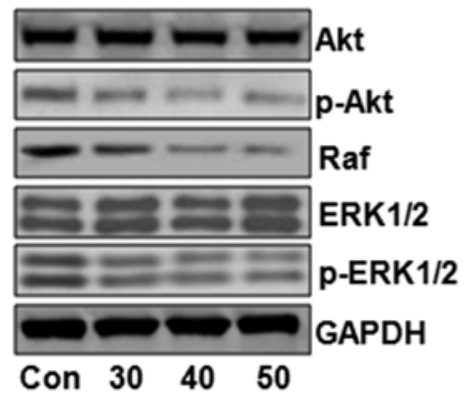

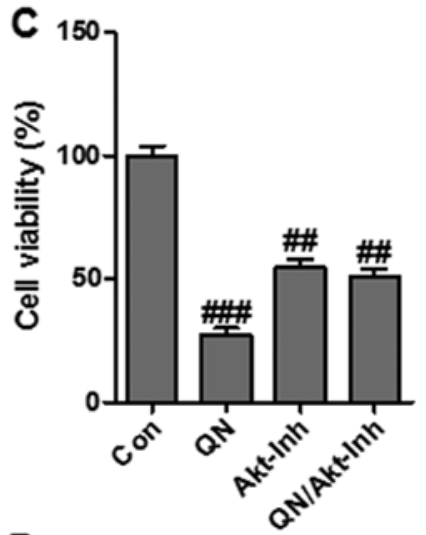

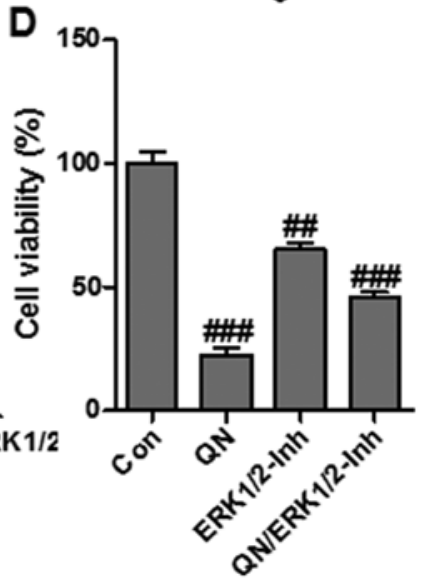

Figure 6. Quercetin nanoparticles suppress liver cancer cell growth through Akt/ERK1/2 signaling inactivation. (A) MHCC97H cells were treated with quercetin nanoparticles. After $48 \mathrm{~h}$, western blotting was conducted to explore the total Akt and phosphorylated Akt, Raf as well as ERK1/2 proteins. (B) The relative protein levels were calculated based on western blot assays. (C) MHCC97H cells were treated with Akt-selective inhibitor (30 $\mu \mathrm{M})$ for $24 \mathrm{~h}$, and then treated with quercetin nanoparticles $(50 \mu \mathrm{g} / \mathrm{ml})$. After $48 \mathrm{~h}$, the cell viability was evaluated via MTT analysis. (D) MHCC97H cells were treated with ERK1/2selective inhibitor $(50 \mu \mathrm{M})$ for $24 \mathrm{~h}$, and then treated with quercetin nanoparticles $(50 \mu \mathrm{g} / \mathrm{ml})$. After $48 \mathrm{~h}$, the cell viability was evaluated via MTT analysis. Data are expressed as the mean $\pm \operatorname{SEM}(\mathrm{n}=6-10) .{ }^{\#} \mathrm{p}<0.05,{ }^{\# \#} \mathrm{p}<0.01$ and ${ }^{\# \#} \mathrm{p}<0.001$ versus the control (Con) group.

did not affect cell viability suppression significantly regulated by COX-2 inhibitor, suggesting that COX-2 signaling pathway was linked with quercetin nanoparticle-regulated liver cancer inhibition. In addition, COX-2 expression was related to the p50 binding activity on the COX-2 promoter structure. Subsequently, we attempted to explore whether quercetin nanoparticle suppressed the binding of $\mathrm{p} 50$ to $\mathrm{COX}-2$ promoter in $\mathrm{MHCC} 97 \mathrm{H}$ cells. Streptavidin-agarose pull-down assay results indicated that treatment with quercetin nanoparticle significantly suppressed p50 binding on COX-2 promoter in comparison with the control group (Fig. 5C). The p50 protein levels were not significantly affected by quercetin nanoparticle (Fig. 5A and B).

$\mathrm{NF}-\kappa \mathrm{B}$ translocation in cell nuclei and cytoplasm plays an important role in modulating COX-2 expression (22). NF- $\mathrm{BB}$ activation was regulated highly by its upstream signals, including IKK $\alpha$ and $\mathrm{I} \kappa \mathrm{B} \alpha(23)$. Fig. 5A shows that quercetin nanoparticle treatment could reduce the phosphorylated IKK $\alpha$ and $\mathrm{I} \kappa \mathrm{B} \alpha$, leading to the alteration of $\mathrm{NF}-\kappa \mathrm{B}$ activation. Immunofluorescence assay was performed to explore the role of quercetin nanoparticle in p50 and NF- $\kappa \mathrm{B}$ translocation through a confocal microscope. Treatment with different concentrations of quercetin nanoparticles caused translocation of $\mathrm{NF}-\kappa \mathrm{B}$ and $\mathrm{p} 50$ from the cell nuclei into cytoplasm (Fig. 5E). The results illustrated that the enhanced suppression of liver cancer cell growth by quercetin nanoparticle might be also regulated, at least partly, through the $\mathrm{p} 50 / \mathrm{NF}-\kappa \mathrm{B} / \mathrm{COX}-2$ pathway in liver cancer cells.

Quercetin nanoparticles suppress liver cancer cell growth through Akt/ERK1/2 signaling inactivation. PI3K/Akt and Raf/ ERK1/2 signaling pathways play essential roles in cancer progression and are involved in the cancer-related gene regulation, including hTERT and COX-2 (24). To determine whether PI3K/Akt and Raf/ERK1/2 signaling pathways were related to quercetin nanoparticle-regulated liver cancer cell growth suppression, we then explored the effect of quercetin nanoparticle on Akt and ERK activity in $\mathrm{MHCC} 97 \mathrm{H}$ cells through western blotting. Quercetin nanoparticle treatment downregulated the phosphorylated Akt and ERK1/2 (Fig. 6A and B). Additionally, the total Akt and ERK1/2 protein levels were not significantly affected by quercetin nanoparticle.

In order to further confirm that quercetin nanoparticle could regulate Akt and ERK pathways to suppress $\mathrm{MHCC} 97 \mathrm{H}$ cell growth, the effect of Akt or ERK1/2-selective inhibitor on quercetin nanoparticle-modulated suppression of cell viability in $\mathrm{MHCC} 97 \mathrm{H}$ cells was calculated. Treatment with Akt inhibitor (Akt-Inh) and ERK1/2 inhibitor (ERK1/2-Inh) downregulated cell viability effectively (Fig. 6C and D). The 

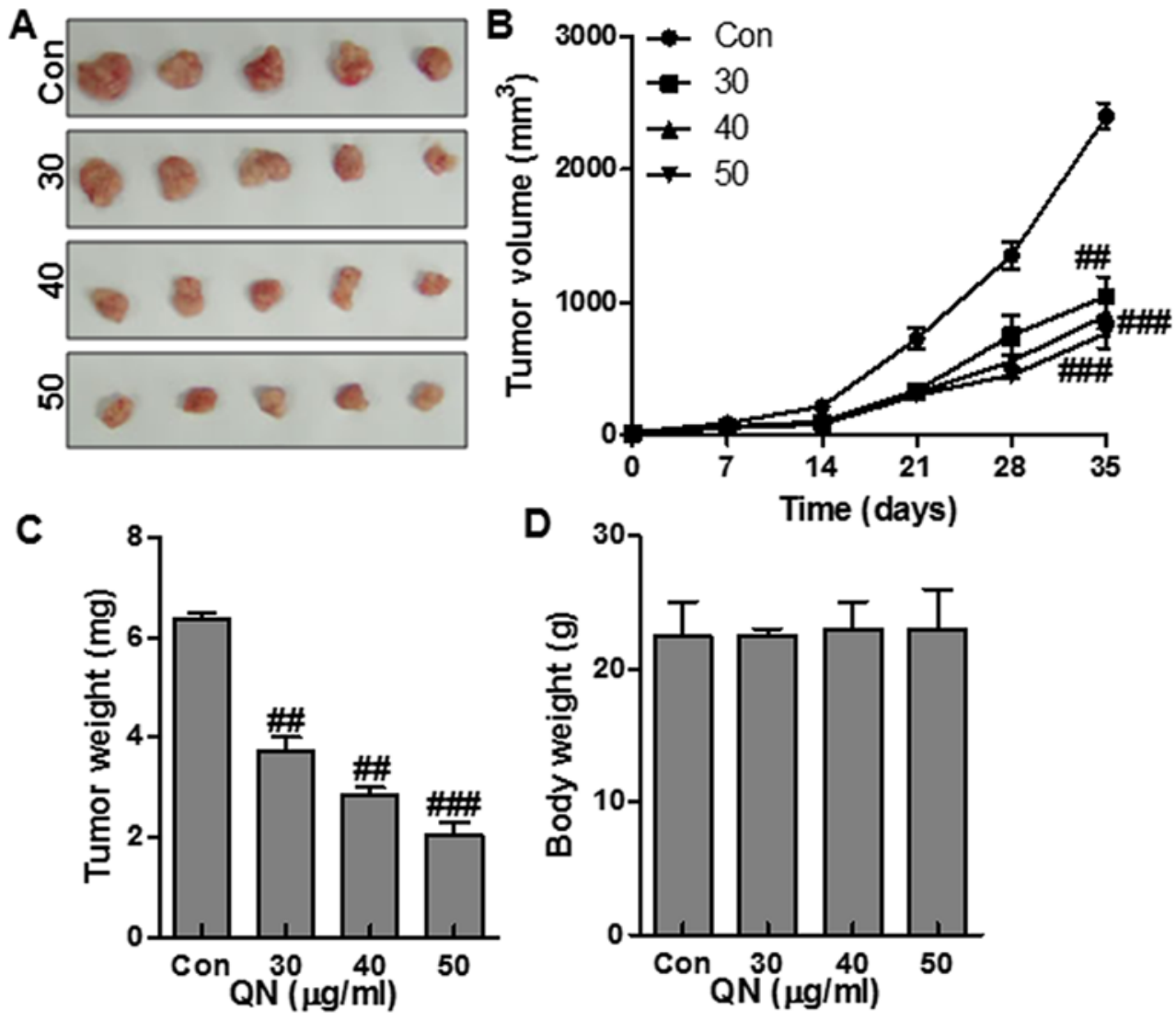

Figure 7. Quercetin nanoparticles inhibit liver cancer growth and progression in xenograft tumor model. (A) MHCC97H cells were injected into the nude mice subcutaneously to explore the role of quercetin nanoparticles. Tumor images are displayed. (B) The tumor volume was measured. (C) The tumor weight was calculated. (D) The body weight of the nude mice was assessed. Data are expressed as the mean \pm SEM $(\mathrm{n}=6-10) .{ }^{\#} \mathrm{p}<0.05$, ${ }^{\# \#} \mathrm{p}<0.01$ and ${ }^{\# \# \#} \mathrm{p}<0.001$ versus the control (Con) group.

data above revealed that Akt/ERK1/2 signaling pathways were important targets for quercetin nanoparticles in suppressing MHCC97H cell growth.

Quercetin nanoparticles inhibit liver cancer growth and progression in xenograft tumor model in vivo. To confirm the role of quercetin nanoparticle in liver cancer growth inhibition, we explored the effects of quercetin nanoparticle on tumorigenicity using an MHCC97H xenograft mouse model in vivo. After administration with quercetin nanoparticles for 35 days, the tumor volumes (Fig. 7A and B) and tumor weights (Fig. 7C) were suppressed significantly by treatment with quercetin nanoparticles. The quercetin nanoparticle treatment did not influence the body weight significantly of the mice (Fig. 7D). These results above supported that quercetin nanoparticle could suppress the xenografted human liver cancer cell growth and proliferation without remarkable adverse effects.

In addition, the IHC staining further illustrated that the tumors in the quercetin nanoparticle-treated groups expressed much lower AP- $2 \beta$ and COX2 levels in comparison to the control group (Fig. 8A and B). In contrast, TUNEL levels were upregulated significantly after quercetin nanoparticle administration, indicating apoptosis was induced by quercetin nanoparticle (Fig. 8A and B). The molecular mechnism by which quercetin nanoparticles inhibited liver cancer progression was explored. As shown in Fig. 8C and D, the Cyto-c/ caspase, P50/NF- $\mathrm{B}$, AP-2 $\beta /$ Htert and Akt/ERK1/2 signaling pathways were inhibited by quercetin nanoparticle administration. As shown in Fig. 8C, the cleaved caspase-9, cleaved caspase- 3 and cytoplasm Cyto-c were downregulated significantly after quercetin nanoparticle treatment. Further, the phosphorylated IKK $\alpha, \mathrm{I} \kappa \mathrm{B} \alpha$ and NF- $\kappa \mathrm{B}$ were reduced in the quercetin nanoparticle-treated groups. In addition, P50 was not altered significantly by quercetin nanoparticle treatment, which was consistent with previous results in vitro (Fig. 8D). Also, AP- $2 \beta$ and Htert were decreased after quercetin nanoparticle administration (Fig. 8E). Finally, the reduced p-Akt, Raf and $\mathrm{p}$-ERK $1 / 2$ further clarified that quercetin nanoparticle had an inhibitory role in liver cancer progression in vivo (Fig. 8F). Our data above indicated that quercetin nanoparticle could suppress liver cancer development via inhibition of Cyto-c/ caspase, P50/NF- $\mathrm{B}, \mathrm{AP}-2 \beta /$ Htert and Akt/ERK1/2 signaling pathways.

\section{Discussion}

Development of effective, novel and safe drugs with lesser side effects and less toxicity is necessary for cancer therapeutic. Phytochemicals are used extensively for their properties in cancer therapeutic (25). Quercetin is a compound investigated for its antiproliferative and anticancerous properties $(26,27)$. The natural flavonoid is considered to be an antioxidant and has inhibitory role in several pathologies. Recently, lipidbased nanocarriers and liposomes have displayed efficacy in 

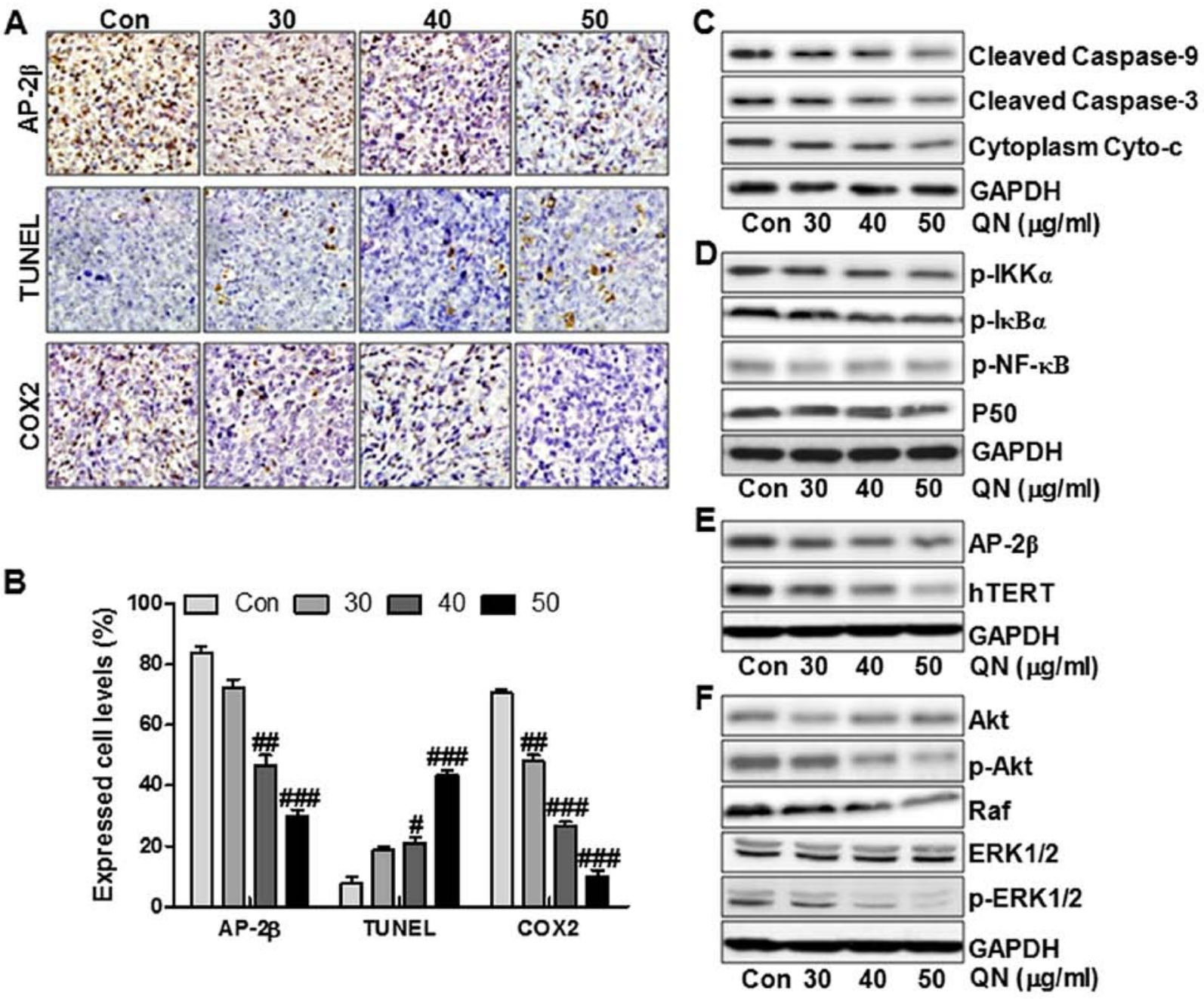

Figure 8. Quercetin nanoparticles inhibite liver cancer development via apoptosis induction and proliferation inhibition in vivo. (A) Histopathology of xenograft tumors. The tumor sections were under IHC staining using antibody against AP-2 $\beta$, TUNEL and COX2. (B) The percentage of AP-2 $\beta$, TUNEL and COX2 positive cells was calculated. Western blot assays were used to evaluate protein levels of cleaved caspase-9, cleaved caspase-3 and Cyto-c (C), p-IKK $\alpha$, p-IKB $\alpha, p-N F-\kappa B$ and P50 (D), AP-2 $\beta$ and hTERT (E), and (F) p-Akt, Raf and p-ERK1/2. Data are expressed as the mean \pm SEM (n=6-10). ${ }^{\# p<0.05, ~}{ }^{\# \#<0.01}$ and ${ }^{\# \# \#} \mathrm{p}<0.001$ versus the control (Con) group.

drug and gene therapy $(14,28,29)$. The successful and effective application of liposome nanocarriers has been catalyzed through targeted delivery and subsequent preferential intracellular uptake, enhancing permeability and retention effect with improved selectivity, efficacy, and overall safety (30). Here, quercetin nanoparticles were used to achieve the promoting effects on liver cancer suppression through multiple cell signaling pathways. The role of quercetin nanoparticles in cell viability, cell morphology, apoptosis, colony formation, as well as cell migration was investigated in our study to reveal the underlying molecular mechanisms. This is the first report that quercetin nanoparticles suppressed liver cancer progression and development via modification of different signaling pathways, including cyclin-D/p27, caspase/Cyto-c, NF- $\mathrm{B} / \mathrm{COX}-2$, AP-2 $\beta /$ hTERT, as well as Akt/ERK1/2, providing possible therapeutic strategies for liver cancer suppression.

We found that quercetin nanoparticles indeed had a potential role in liver cancer cell growth suppression and apoptosis induction. All the results here might serve as a basis for providing the possible treatment of natural anticancer compounds in developing new therapy for liver cancer in future. Dysregulation of cell cycle is a key feature of tumor cells and hence targeting the cell cycle is an important approach in cancer therapy $(31,32)$. Cell cycle machinery is controlled by cyclin-dependent kinase (CDK), cyclins and CDK inhibitory proteins. CDK inhibitory protein, p27, plays an essential role in signaling molecule through regulating the cell cycle progression by interacting with CDK/cyclin complexes directly (33). The expression of $\mathrm{p} 21$ has been investigated in the development of chemotherapeutic drugs, disrupting tumorigenesis via suppressing cell cycle in cancer cells (34). Also, an increased expression of MMPs has been shown to be associated with an invasive phenotype of cancer cells. It is also of paramount importance to note that expressions of MMP-7 are associated with cancer development and progression (35). The inhibition of MMP-7 expression suppresses the tumor invasion and metastatic potential of cancer (36). These results indicated quercetin nanoparticles upregulated p27 in liver cancer cells. Also we found that in the cancer cells treated with quercetin nanoparticles, c-Myc, cyclin-D1, CDK1, MMP7 and $\beta$-catenin were inhibited significantly in a dose-dependent manner, contributing to apoptosis in liver cancer cells. Caspase cascade 
activation forms the important basis for apoptosis. Cyto-c releasing from inter-membrane space of mitochondria into the cytoplasm is known as the precondition of caspase-dependent apoptosis pathway. In our study, the results suggested that quercetin nanoparticles promoted activity of caspases markedly and enhanced the release of Cyto-c from mitochondrial to cytoplasm.

Human telomerase reverse transcriptase (hTERT) is the main subunit of the core enzyme telomerase, which consists of three subunits $(19,37)$. Telomeres are essential for chromosomal stability and integrity, protecting the ends of chromosomes from degradation and preventing chromosomal end fusions and recombination (38). A loss of telomere function is a major mechanism for the generation of chromosomal abnormalities. It is known to express highly in tumors, such as lung cancer. Additionally, hTERT inhibition was found to be effective in proliferation prevention and apoptosis induction (39). hTERT activity is regulated by activating enhancerbinding protein- $2 \beta$ (AP-2 $\beta$ ), which could bind hTERT in the corresponding sites, exerting biological effects via a number of cancer-related genes activation and signaling pathway activity, such as PI3K/Akt, and Raf/ERK1/2 (40). However, no research is available on AP-2 $\beta /$ hTERT signaling pathway by quercetin nanoparticles in human liver cancer cells. In this study, we found that quercetin nanoparticles decreased AP-2 $\beta$ and hTERT expression. Consequently, the liver cancer cell proliferation was inhibited, demonstrating that quercetin nanoparticles had a potential role in suppressing liver cancer via AP-2 $\beta$ and hTERT modulation.

Cyclooxygenase-2 (COX2) is an important effector molecule of inflammation and was reported to be involved in tumor angiogenesis (20). COX2 expression is closely correlated with the malignant transformation and that $\mathrm{COX} 2$ may be used as a molecular marker for the early malignant transformation of cancer progression via inducing cell proliferation, invasion, angiogenesis, and metastasis (41). This study also demonstrated that quercetin nanoparticles displayed an important role in inhibition of COX-2 expression in liver cancer cells. COX2 expressed levels are transcriptionally regulated by multiple transactivators binding and by coactivators on the corresponding sites, which are located in the promoter. $\mathrm{NF}-\kappa \mathrm{B}$ binding site is known as an essential site for COX2 promoter activation $(42,43)$. Due to the enhancement of quercetin nanoparticles on COX2 suppression, we then explored the $\mathrm{NF}-\kappa \mathrm{B}$ alteration in the liver cancer cells. In this study, the promoted suppression of COX 2 expression by quercetin nanoparticles is at least partly regulated by P50 stimulation of the translocation from the nuclear to cytoplasm of liver cancer cells. In addition, our data revealed the increased inhibitory role of quercetin nanoparticles in liver cancer cells by impeding the $\mathrm{P} 50$ binding to COX 2 promoter. Also, Akt/ ERK1/2 signaling pathway, performs a crucial role in cell apoptosis, proliferation and autology (44). In our study, we found that quercetin nanoparticles downregulated the phosphorylated Akt and ERK1/2 activity, which was important for liver cancer inhibition.

In conclusion, quercetin nanoparticles enhanced the inhibitory role in liver cancer progression through multiple routes of action, including caspase/Cyto-c activation, AP-2 $\beta /$ hTERT inhibition, $\mathrm{NF}-\kappa \mathrm{B} / \mathrm{COX}-2$ and $\mathrm{Akt} / \mathrm{ERK} 1 / 2$ suppression.
Therefore, our results suggest that quercetin nanoparticle is a promising candidate in liver cancer therapeutics in future. However, the molecular mechanism of the anti-proliferative and apoptotic effects of quercetin nanoparticles remains to be determined.

\section{References}

1. Marquardt JU, Andersen JB and Thorgeirsson SS: Functional and genetic deconstruction of the cellular origin in liver cancer. Nat Rev Cancer 15: 653-667, 2015.

2. Torre LA, Bray F, Siegel RL, Ferlay J, Lortet-Tieulent J and Jemal A: Global cancer statistics, 2012. CA Cancer J Clin 65: 87-108, 2015

3. Chatterjee R and Mitra A: An overview of effective therapies and recent advances in biomarkers for chronic liver diseases and associated liver cancer. Int Immunopharmacol 24: 335-345, 2015.

4. Bruix J, Raoul JL, Sherman M, Mazzaferro V, Bolondi L, Craxi A, Galle PR, Santoro A, Beaugrand M, Sangiovanni A, et al: Efficacy and safety of sorafenib in patients with advanced hepatocellular carcinoma: Subanalyses of a phase III trial. J Hepatol 57: 821-829, 2012.

5. Davis JM, Murphy EA and Carmichael MD: Effects of the dietary flavonoid quercetin upon performance and health. Curr Sports Med Rep 8: 206-213, 2009.

6. Wiczkowski W, Romaszko J, Bucinski A, Szawara-Nowak D, Honke J, Zielinski H and Piskula MK: Quercetin from shallots (Allium cepa L. var. aggregatum) is more bioavailable than its glucosides. J Nutr 138: 885-888, 2008.

7. Guo Y, Mah E, Davis CG, Jalili T, Ferruzzi MG, Chun OK and Bruno RS: Dietary fat increases quercetin bioavailability in overweight adults. Mol Nutr Food Res 57: 896-905, 2013.

8. Aguirre L, Arias N, Macarulla MT, Gracia A and Portillo MP: Beneficial effects of quercetin on obesity and diabetes. Open Nutraceuticals J 4: 189-198, 2011.

9. Bhattacharyya SS, Paul S, De A, Das D, Samadder A, Boujedaini N and Khuda-Bukhsh AR: Poly (lactide-co-glycolide) acid nanoencapsulation of a synthetic coumarin: Cytotoxicity and bio-distribution in mice, in cancer cell line and interaction with calf thymus DNA as target. Toxicol Appl Pharmacol 253: 270-281, 2011.

10. Lee KM, Hwang MK, Lee DE, Lee KW and Lee HJ: Protective effect of quercetin against arsenite-induced COX-2 expression by targeting PI3K in rat liver epithelial cells. J Agric Food Chem 58: 5815-5820, 2010.

11. Tan J, Wang S, Yang J and Liu Y: Coupled particulate and continuum model for nanoparticle targeted delivery. Comput Struc 122: 128-134, 2013

12. Wang S, Zhou Y, Tan J, Xu J, Yang J and Liu Y: Computational modeling of magnetic nanoparticle targeting to stent surface under high gradient field. Comput Mech 53: 403-412, 2014.

13. Puhl AC, Fagundes M, dos Santos KC, Polikarpov I, das Gracas MF, da Silva F, Fernandes JB, Vieira PC and Forim MR: Preparation and characterization of polymeric nanoparticles loaded with the flavonoid luteolin, by using factorial design. Int J Drug Deliv 3: 683-698, 2011.

14. Pinzón-Daza ML, Campia I, Kopecka J, Garzón R, Ghigo D and Riganti C: Nanoparticle- and liposome-carried drugs: New strategies for active targeting and drug delivery across blood-brain barrier. Curr Drug Metab 14: 625-640, 2013.

15. Alvarez-Erviti L, Seow Y, Yin H, Betts C, Lakhal S and Wood MJ: Delivery of siRNA to the mouse brain by systemic injection of targeted exosomes. Nat Biotechnol 29: 341-345, 2011.

16. Xie Y, Ye L, Zhang X, Cui W, Lou J, Nagai T and Hou X: Transport of nerve growth factor encapsulated into liposomes across the blood-brain barrier: In vitro and in vivo studies. J Control Release 105: 106-119, 2005.

17. Hosta-Rigau L, Schattling P, Teo BM, Lynge ME and Städler B: Recent progress of liposomes in nanomedicine. J Mater Chem B Mater Biol Med 2: 6686-6691, 2014

18. Sapra P and Allen TM: Ligand-targeted liposomal anticancer drugs. Prog Lipid Res 42: 439-462, 2003.

19. Zheng YL, Zhang F, Sun B, Du J, Sun C, Yuan J, Wang Y, Tao L, Kota K, Liu X, et al: Telomerase enzymatic component hTERT shortens long telomeres in human cells. Cell Cycle 13: 1765-1776, 2014. 
20. Kuźbicki Ł, Lange D, Stanek-Widera A and Chwirot BW: Different expression of cyclooxygenase-2 (COX-2) in selected nonmelanocytic human cutaneous lesions. Folia Histochem Cytobiol 49: 381-388, 2011.

21. Müller-Decker K: Cyclooxygenase-dependent signaling is causally linked to non-melanoma skin carcinogenesis: Pharmacological, genetic, and clinical evidence. Cancer Metastasis Rev 30: 343-361, 2011.

22. Han S, Lee JH, Kim C, Nam D, Chung WS, Lee SG, Ahn KS, Cho SK, Cho M and Ahn KS: Capillarisin inhibits iNOS, COX-2 expression, and proinflammatory cytokines in LPS-induced RAW 264.7 macrophages via the suppression of ERK, JNK, and NF- $\kappa \mathrm{B}$ activation. Immunopharmacol Immunotoxicol 35: 34-42, 2013.

23. Hsiang CY, Lo HY, Huang HC, Li CC, Wu SL and Ho TY: Ginger extract and zingerone ameliorated trinitrobenzene sulphonic acid-induced colitis in mice via modulation of nuclear factor- $\kappa B$ activity and interleukin- $1 \beta$ signalling pathway. Food Chem 136 : 170-177, 2013

24. Wang J, Xiao X, Zhang Y, Shi D, Chen W, Fu L, Liu L, Xie F, Kang T, Huang W, et al: Simultaneous modulation of COX-2, p300, Akt, and Apaf-1 signaling by melatonin to inhibit proliferation and induce apoptosis in breast cancer cells. J Pineal Res 53: 77-90, 2012.

25. Tsao R: Chemistry and biochemistry of dietary polyphenols Nutrients 2: 1231-1246, 2010.

26. Dong YS, Wang JL, Feng DY, Qin HZ, Wen H, Yin ZM, Gao GD and Li C: Protective effect of quercetin against oxidative stress and brain edema in an experimental rat model of subarachnoid hemorrhage. Int J Med Sci 11: 282-290, 2014.

27. Kobori M, Takahashi Y, Sakurai M, Akimoto Y, Tsushida T, Oike H and Ippoushi K: Quercetin suppresses immune cell accumulation and improves mitochondrial gene expression in adipose tissue of diet-induced obese mice. Mol Nutr Food Res 60 300-312, 2016.

28. Iyer AK, Khaled G, Fang $\mathbf{J}$ and Maeda $\mathrm{H}$ : Exploiting the enhanced permeability and retention effect for tumor targeting. Drug Discov Today 11: 812-818, 2006.

29. Cho HJ, Yoon HY, Koo H, Ko SH, Shim JS, Lee JH, Kim K, Kwon IC and Kim DD: Self-assembled nanoparticles based on hyaluronic acid-ceramide (HA-CE) and Pluronic ${ }^{\circledR}$ for tumortargeted delivery of docetaxel. Biomaterials 32: 7181-7190, 2011.

30. Sharma VK, Mishra D, Sharma A and Srivastava B: Liposomes: Present prospective and future challenges. Int J Current Pharm Rev Res 1: 6-16, 2010.

31. Barré B and Perkins ND: A cell cycle regulatory network controlling NF-kappaB subunit activity and function. EMBO J 26: 4841-4855, 2007.

32. Fu Y, Kadioglu O, Wiench B, Wei Z, Gao C, Luo M, Gu C, Zu Y and Efferth T: Cell cycle arrest and induction of apoptosis by cajanin stilbene acid from Cajanus cajan in breast cancer cells. Phytomedicine 22: 462-468, 2015.
33. Satyanarayana A, Hilton MB and Kaldis P: p21 Inhibits Cdk1 in the absence of Cdk2 to maintain the G1/S phase DNA damage checkpoint. Mol Biol Cell 19: 65-77, 2008.

34. Campomenosi P, Monti P, Aprile A, Abbondandolo A, Frebourg T, Gold B, Crook T, Inga A, Resnick MA, Iggo R, et al: p53 mutants can often transactivate promoters containing a p21 but not Bax or PIG3 responsive elements. Oncogene 20: 3573-3579, 2001.

35. Chien CS, Shen KH, Huang JS, Ko SC and Shih YW: Antimetastatic potential of fisetin involves inactivation of the PI3K/Akt and JNK signaling pathways with downregulation of MMP-2/9 expressions in prostate cancer PC-3 cells. Mol Cell Biochem 333: 169-180, 2010.

36. Chen JS, Wang Q, Fu XH, Huang XH, Chen XL, Cao LQ Chen LZ, Tan HX, Li W, Bi J, et al: Involvement of PI3K/PTEN/ AKT/mTOR pathway in invasion and metastasis in hepatocellular carcinoma: Association with MMP-9. Hepatol Res 39: 177-186, 2009.

37. Choi SH, Im E, Kang HK, Lee JH, Kwak HS, Bae YT, Park HJ and Kim ND: Inhibitory effects of costunolide on the telomerase activity in human breast carcinoma cells. Cancer Lett 227: $153-162,2005$

38. Kim MO, Moon DO, Kang SH, Heo MS, Choi YH, Jung JH, Lee JD and Kim GY: Pectenotoxin-2 represses telomerase activity in human leukemia cells through suppression of hTERT gene expression and Akt-dependent hTERT phosphorylation. FEBS Lett 582: 3263-3269, 2008.

39. Di Stefano AL, Enciso-Mora V, Marie Y, Desestret V, Labussière M, Boisselier B, Mokhtari K, Idbaih A,Hoang-Xuan K, Delattre JY, et al: Association between glioma susceptibility loci and tumour pathology defines specific molecular etiologies. Neuro-oncol 15: 542-547, 2013.

40. Deng WG, Jayachandran G, Wu G, Xu K, Roth JA and Ji L: Tumor-specific activation of human telomerase reverses transcriptase promoter activity by activating enhancer-binding protein-2beta in human lung cancer cells. J Biol Chem 282: 26460-26470, 2007

41. Kajita S, Ruebel KH, Casey MB, Nakamura N and Lloyd RV: Role of COX-2, thromboxane A2 synthase, and prostaglandin I2 synthase in papillary thyroid carcinoma growth. Mod Pathol 18: 221-227, 2005.

42. Wang D and Dubois RN: The role of COX-2 in intestinal inflammation and colorectal cancer. Oncogene 29: 781-788, 2010.

43. Deng WG, Zhu Y and Wu KK: Role of p300 and PCAF in regulating cyclooxygenase-2 promoter activation by inflammatory mediators. Blood 103: 2135-2142, 2004.

44. Fu L, Chen W, Guo W, Wang J, Tian Y, Shi D, Zhang X, Qiu H, Xiao X, Kang T, et al: Berberine Targets AP-2/hTERT, NF- $\kappa \mathrm{B} /$ COX-2, HIF-1 $\alpha /$ VEGF and Cytochrome-c/caspase signaling to suppress human cancer cell growth. PLoS One 8: e69240, 2013. 